\title{
Effect of Return on Assets, Debt to Equity Ratio, Earning Per Share, Dividend Payout Ratio, Price to Book Value and Earning Growth to Price Earnings Rasio (In Companies Incorporated in the LQ45 Index for the Period 2011 - 2015)
}

\author{
Bambang Tri Utomo ${ }^{1}$, Mia Laksmiwati ${ }^{2}$ \\ \{bambang.triutomo@budiluhur.ac.id ${ }^{1}$, mia.laksmiwati@budiluhur.ac.id $\left.{ }^{2}\right\}$ \\ Faculty of Economy and Business Universitas Budi Luhur, Jl. Ciledug Raya, Jakarta, Indonesia ${ }^{1,2}$
}

\begin{abstract}
One of the fundamental analysis most commonly used by investors and securities analysts in assessing the price of a stock is by Price Earnings Ratio (PER) approach, which illustrates the willingness of an investor to pay a certain amount for each IDR earnings company. The purpose of this study is to analyze the variables that affect the Price Earnings Ratio of companies incorporated in the LQ 45 period 2011-2016. The variables are Return on Assets, Debt to Equity Ratio, Earning per Share, Dividend Payout Ratio, Price to Book Value and Earning Growth. Sampling was done by purposive sampling and resulted 22 companies. The analysis technique use multiple linear regression. Hypothesis testing is done by using $t$ test and model feasibility test. The result of research shows that the variable of Return On Assets, Dividend Payout Ratio, and Price To Book Value have positive and significant effect to Price Earnings Ratio, while Debt to Equity Ratio, Earning Per Share and Earning Growth variables have negative and not significant effect on Price Earnings Ratio. The coefficient of determination of 0.865 which means that the ability of the regression model to predict is $86.5 \%$.
\end{abstract}

Keywords: Return on Assets, Debt to Equity Ratio, Dividend Payout Ratio, Price to Book Value, Price Earnings Ratio.

\section{Introduction}

Capital market as a market for various financial instruments or long-term securities that can be traded, either in the form of debt or equity, issued by the government, public authorities, or private companies. So that the capital market is a financial institution that can be used as a medium of financing for developing companies to offer their valuable letter either in the form of bonds or in the form of shares with an intermediary company underwriter.

One of the most preferred investment options in the stock market is stock. One of the characteristics that can be selected by an investor is LQ 45 index stock in Indonesia Stock Exchange. Every three months will be reviewed the movement of stock rankings used in the calculation index LQ 45. Substitution of shares will be done every six months, ie every early February and August. 
This research emphasizes on fundamental analysis that is by using Price Earnings Ratio (PER) approach also called Earning Multiplier. Price Earnings Ratio (PER) is used to assess the fairness of stock prices, because PER facilitates or helps judgment in analyzing stock investments. Previous studies on the relationship between several components of financial variables to Price Earnings Ratio were performed by Yulia et al. [1], Djazuli and Kiptiyah [2], Permatasari and Yonowati [3], Susanto and Wiksuana [4], Kartika Sari and Gusti Putu Wirawati [5]. Among these studies there are still inconsistencies from previous studies in some variables such as Return on Assets (ROA), Debt to Equity Ratio (DER), Earning per Share (EPS), Dividend Payout Ratio (DPR), Price to Book Value (PBV) and Earning Growth (EG).

\subsection{Theoretical Review}

This analysis will compare the intrinsic value of a stock to its market price in order to determine whether the stock's price already reflects its intrinsic value or not. The intrinsic value of a stock is determined by the fundamental factors influencing the basic idea of this approach is that the stock price will be influenced by the firm's performance. The performance of the company itself is influenced by macro industrial and economic conditions [6].

\subsubsection{Price Earnings Ratio}

Basically this ratiogives an indication of the time period needed to return the funds at the level of stock prices and corporate profits at a certain period. Therefore, this ratio illustrates the willingness of an investor to pay a certain amount for each rupiah of corporate profits.

\subsubsection{Return on Assets}

Like, Fahmi (2015) say, the ratio to see the extent to which the investment or total assets that have been implanted able to provide returns on profits as expected [7]. This like Sjahrial(2012) told [8].

\subsubsection{Debt to Equity Ratio}

According to Kasmir (2015), the ratio used to assess debt with equity [9].

\subsubsection{Earning Per Share}

According to Fahmi(2015), this ratiodescribesa form of profit given to the shareholders of each share shares owned [7].

\subsubsection{Dividend Payout Ratio}

The ratio shows the comparison between cash dividends per share and earnings per share or this represents the amount of profit per share in dividends [10]. 


\subsubsection{Price to Book Value}

Harjadi (2013) say,this ratio describes how much the market appreciates the value of a company's books. PBV does not contain information about the company's ability to generate profits [11].

\subsubsection{Earnings Growth}

Earning Growth or profit growth represents the company's growth from year to year. Profit growth to be studied is the growth of earnings per share, like Sjahrial (2012) told [8].

\subsection{Restricting The Problem}

1. This research is limited toReturn on Assets, Debt to Equity Ratio, Earning per Share, Dividend Payout Ratio, Price to Book Value and Earning Growth.

2. Companies incorporated in the LQ 45 Index listed on the Stock Exchange and have published the financial statements continuously in the period 2011-2015.

3. Share price is the average stock price of Closing Price during January - December

\subsection{Formulation of the Problem}

1. Does Return on Assets have a significant effect on Price Earnings Ratio?

2. Does Debt to Equity Ratio have a significant effect on Price Earnings Ratio?

3. Does Earning per Share have a significant effect on Price Earnings Ratio?

4. Does Dividend Payout Ratio, significant effect on Price Earnings Ratio?

5. Does Price to Book Value have a significant effect on Price Earnings Ratio?

6. Does Earning Growth have a significant effect on Price Earnings Ratio?

\subsection{Research Hypotheses}

H1: Return On Assets effect on Price Earnings Ratio

H2: Debt to Equity Ratio has an effect on Price Earnings Ratio

H3: Earning Per Sharehas an effect on Price Earnings Ratio

H4: Dividend Payout Ratio effect on Price Earnings Ratio

H5: Price to Book Value has an effect on Price Earnings Ratio

H6: Earning Growth effect on Price Earnings Ratio 


\subsubsection{Framework of Thinking}

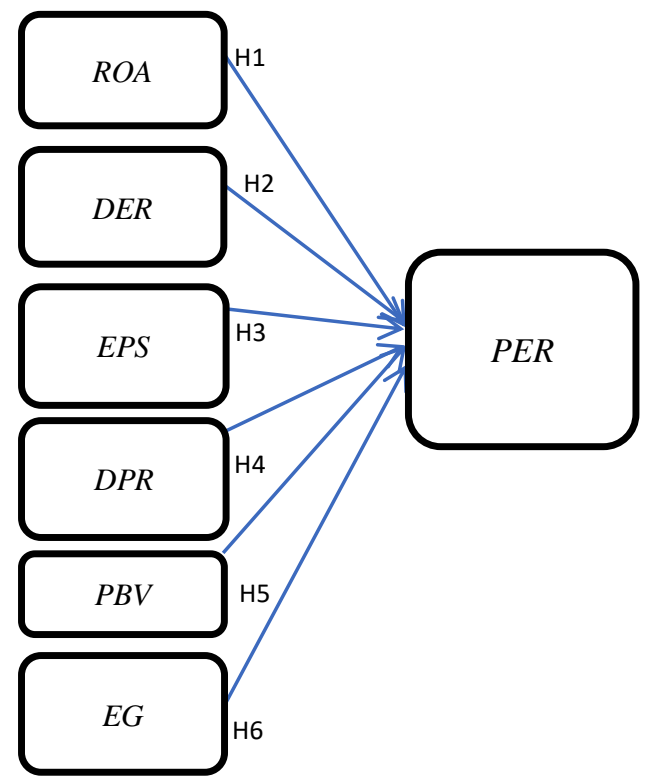

Fig. 1. Framework of Thinking.

\section{Research Methodology}

This research is a type of quantitative research by analyzing secondary data and the population is 45 companies incorporated in LQ 45 Index. Researchers use documentary type data obtained from Indonesia Stock Exchange which became the subject of this study. Sources of data arefinancial reports.

Data analysis with multiple regression analysis with SPSS 20 program and with Multicolinierity Test, Autocorrelation test, Normality Test and Heteroskedasticity Test and Hypothesis Testing with t test and model feasibility test.

\subsection{Sample Research}

Purposive sampling technique is used in this research where the technique of determining the sample with certain considerations. The considerations implied in determining the sample of this study are: (1) Companies incorporated in the LQ 45 Index listed on the Stock Exchange which have the most complete financial statements and have been published in 2011-2015. (2) Companies are still operating during the observation period (2011 to 2015). Based on these two criteria, the sample of 22 companies in the LQ 45. Index listed in the Indonesia Stock Exchange for 2011-2015 period is obtained. 


\section{Results of Research}

\subsection{Normality Test}

Table 1. Normality Test.

One-Sample Kolmogorov-Smirnov Test

\begin{tabular}{|ll|r|}
\hline & & $\begin{array}{r}\text { Unstandardiz } \\
\text { ed Residual }\end{array}$ \\
\hline $\mathrm{N}$ & Mean & 110 \\
Normal Parameters & a,b & .0500698 \\
Most Extreme Differences & Std. Deviation & .19146961 \\
& Absolute & .043 \\
& Positive & .034 \\
Kolmogorov-Smirnov Z & Negative & -.043 \\
Asymp. Sig. (2-tailed) & & .455 \\
\hline
\end{tabular}

a. Test distribution is Normal.

b. Calculated from data.

Source: SPSS version 20 results.

In table 1 seen significant value of $0.986>0.05$ so it can be said that this model is normally distributed.

\subsection{Autocorrelation Test}

Table 2. Autocorrelation Test.

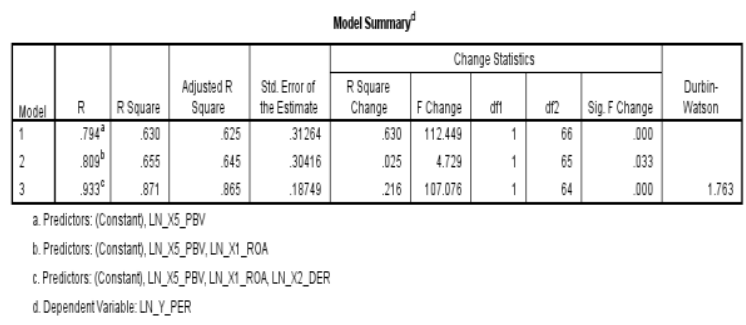

Source: SPSS version 20 results.

Based on Table 2 then DW calculated equal to 1.763 between dL of 1.4217 and dU 1.8032 which means it can be concluded the model does not occur autocorrelation. 
Table 3. Run Test.

\section{Runs Test}

\begin{tabular}{|l|r|}
\hline & $\begin{array}{c}\text { Unstandardiz } \\
\text { ed Residual }\end{array}$ \\
\hline Test Value & .04991 \\
Cases < Test Value & 55 \\
Cases >= Test Value & 55 \\
Total Cases & 110 \\
Number of Runs & 53 \\
Z & -.575 \\
Asymp. Sig. (2-tailed) & .565 \\
\hline
\end{tabular}

a. Median

Based on table 3 then it can be seen Run test results with significant value of $0,565>0,05$ therefore this model is free from Autocorrelation problem.

\subsection{Multicolinearity Test}

Table 4. Multicolinearity Test.

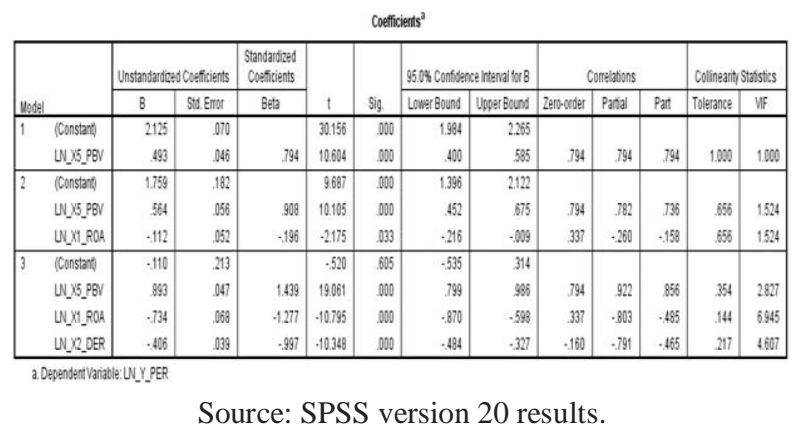

Based on table 4 it can be seen that the value of variance inflation factor (VIF) of each independent variable has a VIF of no more than 10 and a Tolerance value of not less than 0.1 . Thus, it can be concluded that all independent variables (Price to Book Value and Return On Assets and Debt to Equity Ratio) does not occur multicollinearity problems and can be used as research data.

\subsection{Heteroscedasticity Test}

From Figure 2, the scatterplot shows that the points spread randomly, do not form a certain clear pattern, and spread either above or below the number 0 on the $\mathrm{Y}$ axis, it can be concluded that there is no heteroscedasticity in this regression model, so the model is feasible used. 


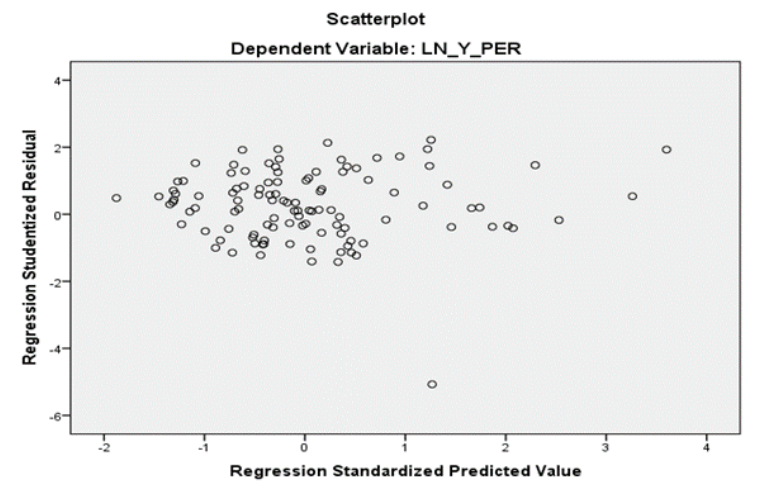

Fig. 2. Heteroscedasticity Test.

\subsection{Determination Coefficient Analysis}

Table 5. Determination Coefficient.

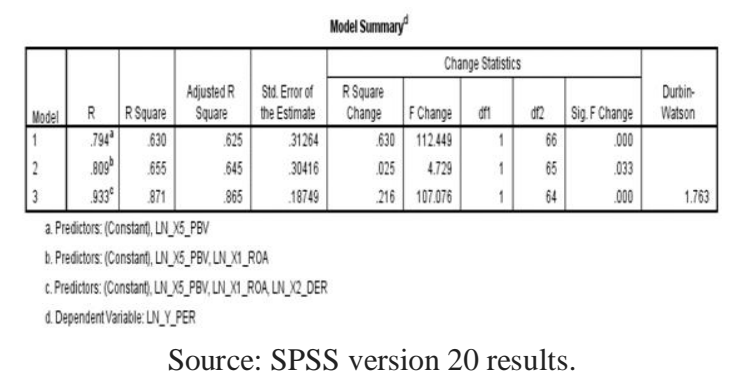

From table 5 Adjusted R Square equal to 0,865 or $86,5 \%$, meaning fluctuation of PER can be explained by PBV, ROA and DER and the rest $13,5 \%(100 \%-86.5 \%)$ is explained by other things outside the research model such as Company Size, Return On Equity and so on.

\subsection{Multiple Linear Regression Analysis}

Table 6. Multiple Linear Regression.

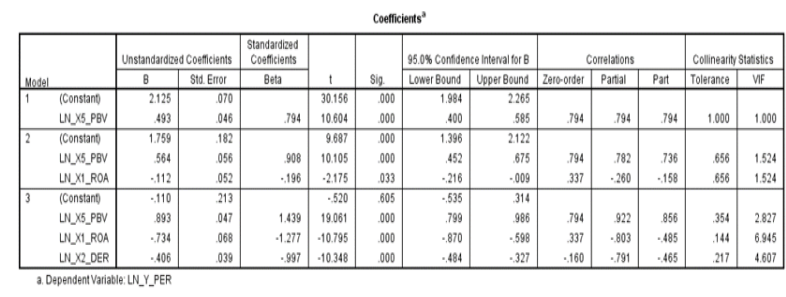

Source: SPSS version 20 results.

Based on table 6 can be seen the regression equation: 


$$
\text { Y_PER }=-110-0.734 L N \_X 1 \_R O A-0.406 L N \_X 2 \_D E R+0.893 L N \_X 5 \_P B V
$$

The regression equation can be interpreted as follows:

- Constant is -110: it means that if ROA, DER and PBV value is 0, then PER value is - 110

- Regression coefficient of ROA equal to -0.734: means if other independent variables are fixed and if ROA increases 1 unit, then PER will decrease by 0.734 .

- Regression coefficient of DER is -0,040: it means that if other independent variables are fixed and if DER increases 1 unit, then PER will decrease by 0,040 .

- Regression coefficient of PBV is 0.893: it means that if other independent variables are fixed and if PBV increases 1 unit, then PER will decrease by 0.893 .

Table 7. $t$ Test.

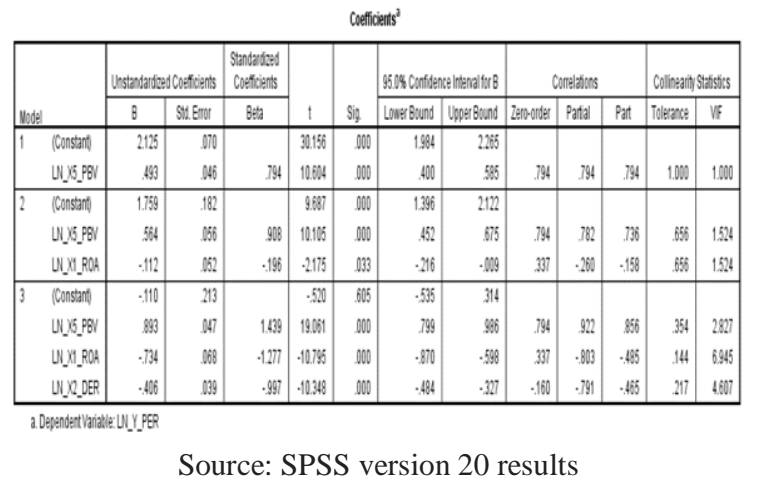

From table 7 the results are as follows:

1. Sig value. variable ROA of $0,000<0.05$ which means the variable ROA effect on PER

2. Sig value. variable DER of $0,000<0,05$ which means DER variable has an effect on PER

3. Sig value. PBV variable is $0.000<0,05$ which means PBV variable has an effect on PER

Table 8. Model Feasibility Test.

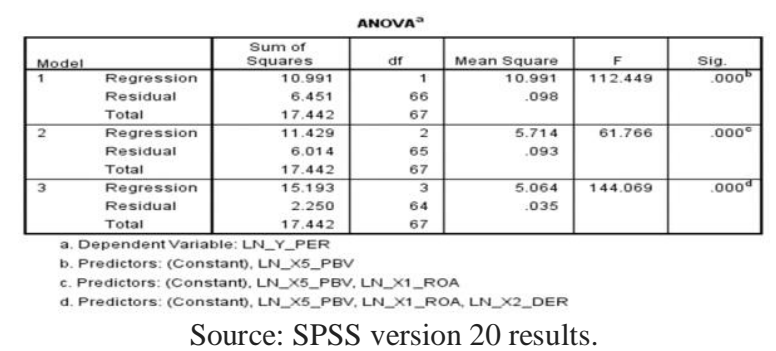

From table 8, the result of Sig value. $0.000<0.05$ which means there is a significant influence between ROA,DER, EPS, DPR, PBV and EGsimultaneously to PER. 


\subsection{Interpretation of Research Results}

a. Effect ROA against PER :

Return On Asset has a significant effect on Price Earning Ratio. If ROA is high, then the company has the ability to generate profits so that investors will be more confident that investing will be profitable. This research is in line with research conducted by Permataari and Yonowati [3], Yulia et al., [1], Susanto and Wiksuana [4] that ROA has a significant effect on PER.

b. Effect DER against PER

Debt to Equity Ratio significantly influence Price Earning Ratio (PER). Increased debt will result in an increased risk so that market confidence in the growth prospects of the company will be reduced and create a low share price and result in a smaller PER. The greater this ratio, the more unfavorable it will be because the greater the risk borne of the failure that may occur in the company for both creditors and shareholders. This research is in line with research conducted by Yulia et al(2014) that DER have a significant effect on PER [1].

\section{c. Effect of EPS on PER}

Earnings Per Share has no significant effect on Price Earning Ratio. EPS is not a reflection of company profits. Companies that have the same EPS, but if the amount of total assets are different there aslo the profit. This research is in line with research conducted by Yulia et al(2014) that EPS has no significant effect on PER [1].

d. Effect of DPR on PER

Dividend Payout Ratio does not significantly affect the Price Earning Ratio. Changes on the dividend payout ratio can affect the PER change. A company makes a profit but its dividend is not distributed to investors because it is invested / bought assets. If dividend income of a company's stock is unstable then the stock price is unstable as well. This research is in line with research conducted by Yulia et al(2014) that DPR has no significant effect on PER [1].

e. Effect of PBV on PER

Price to Book Value significantly influence Price Earning Ratio. The greater the value of PBV, the higher the value of the firm. So that makes the investors interested to invest funds into the company. This will have an impact on the increasing number of investors who are interested in the shares of the company and resulted in rising prices in the capital market. This research is in line with research conducted by Yulia et al(2014) that PBV has significant effect on PER [1].

f. Effect of EG on PER

The results that have been done, it is known that Earning Growth has no significant effect on Price Earning Ratio. The average company has a negative profit growth so that Earning per Share does not reflect corporate earnings. Companies that have the same Earning per Share, total assets are different then the profit is different. This research is in line with research conducted by Yulia et al (2014) and (Djazuli and Kiptiyah, 2009) that EG has no significant effect on PER [1], [2]. 


\section{Conclusion}

There is a significant influence between variable ROA, DER and PBV to PERand no significant influence between variable EPS, DPR and EG to PER in companies incorporated in Index LQ 45. Investors should consider the variable ROA, DER and PBV if they want to invest in shares of companies and companies incorporated in the LQ 45 Index should increase the EPS, DPR and EG in order to attract investors to invest in stocks. The next researcher is to add other independent variables which influence to PER, that is, among others: Return On Equity, Company Size as well as using companies engaged in some sectors and other subsectors, for further research get better and useful results.

\section{References}

[1]E. Yulia et al., "Erlin Yulia Rahma, Djumahir, Atim Djazuli,” J. Apl. Manaj., vol. 12, no. 3, 2014.

[2]A. Djazuli and S. M. Kiptiyah, "Analisis Variabel-Variabel Fundamental Yang Berpengaruh Terhadap Price Earning Ratio Sebagai Dasar Penilaian Saham,” vol. 12, no. 4, pp. 678-696, 2009.

[3]R. Permatasari and T. Yonowati, "Analisa Faktor Keuangan Yang Mempengaruhi Price Earning," vol. 5, 2016.

[4]A. Susanto and I. G. B. Wiksuana, "Non Performing Loan Dan Beban Operasional Terhadap Pendapatan Operasional Sebagai Prediktor Return On Asset Serta Pengaruhnya Terhadap Price Earning Ratio Pada Perusahaan Perbankan Di Bursa Efek Indonesia," vol. 11, pp. 674-688, 2014.

[5]C. Kartika Sari and N. Gusti Putu Wirawati, "Pengaruh Rasio Keuangan Indikator Kesehatan Bank Pada Price Earning Ratio Perusahaan Perbankan,” J. Akunt. Univ. Udayana, vol. 131, pp. 2302-8556, 2015.

[6]A. Halim, Analisis Infestasi dan Aplikasinya. Jakarta: Salemba Empat, 2015.

[7]I. Fahmi, Manajemen Investasi Teori dan Soal Jawab. Jakarta: Salemba Empat, 2015.

[8]D. Sjahrial, Pengantar Manajemen Keuangan. Jakarta: Mitra Wacana Media, 2012.

[9]Kasmir, Analisis Laporan Keuangan. Jakarta: Rajawali Pers, 2015.

[10]D. Sussanto, Herry dan Nurliana, "Analisis Pengaruh Faktor Fundamental Dan Risiko Sistematik Terhadap Harga Saham Pada Perusahaan Perdagangan Di Bei," J. Ekon. Bisnis, vol. 14, pp. 19-27, 2009.

[11]S. Harjadi, Pasar Modal Indonesia Pengantar dan Analisis. Jakarta: In Media, 2013. 